\title{
Innovative backfilling longwall panel layout for better subsidence control effect-separating adjacent subcritical panels with pillars
}

\author{
Jialin Xu • Dayang Xuan $\cdot$ Changchun He
}

Received: 20 January 2014/Revised: 10 February 2014/ Accepted: 10 February 2014/Published online: 10 October 2014

(C) The Author(s) 2014. This article is published with open access at Springerlink.com

\begin{abstract}
In recent years, field trials of non-pillar longwall mining using complete backfill have been implemented successively in the Chinese coal mining industry. The objective of this paper is to get a scientific understanding of surface subsidence control effect using such techniques. It begins with a brief overview on complete backfill methods primarily used in China, followed by an analysis of collected subsidence factors under mining with complete backfill. It is concluded that non-pillar longwall panel layout cannot protect surface structures against damages at a relatively large mining height, even though complete backfill is conducted. In such cases, separated longwall panel layout should be applied, i.e., panel width should be subcritical and stable coal pillars should be left between the adjacent panels. The proposed method takes the principles of subcritical extraction and partial extraction; in conjunction with gob backfilling, surface subsidence can be effectively mitigated, thus protecting surface buildings against mining-induced damage. A general design principle and method of separated panel layout have also been proposed.
\end{abstract}

Keywords Mining with backfill $\cdot$ Longwall mining $\cdot$ Surface subsidence control $\cdot$ Subcritical panel width $\cdot$ Separated pillar

\section{Introduction}

Backfill involves placing any waste material into minedout area (or other mining-induced voids, e.g., horizontal fractures in overburden) for the purpose of either disposal or to perform some engineering function, e.g., ground and subsidence control (Grice 1998). In the coal mining industry worldwide, the primary and common purpose of applying backfill is to mitigate surface subsidence and thus to mine under surface structures (the most cases), rivers and railways, etc. (Palarski 1989, 2004; Karfakis et al. 1996; Ilgner 2000; Xu et al. 2004; Lokhande et al. 2005;

J. Xu $(\bowtie) \cdot$ D. Xuan · C. He

State Key Laboratory of Coal Resources and Safe Mining, China University of Mining and Technology, Xuzhou 221116, China e-mail: cumtxj1@cumt.edu.cn

J. Xu $\cdot$ D. Xuan $\cdot$ C. He

School of Mines, China University of Mining and Technology,

Xuzhou 221116, China
Miao et al. 2010; Xuan et al. 2013; Xuan and Xu 2014). In underground coal mines, surface subsidence induced by different mining methods are very different. Therefore, the demands for backfill vary significantly in light of the mining methods used.

Globally, three primary mining methods were developed for the underground coal mining: longwall, room and pillar, and panel and pillar. Under room and pillar mining, if depillaring is not employed, the extraction ratio is typically $<50 \%$ and little surface subsidence occurs (Peng 1992). Therefore, backfilling is not required and conducted at all unless some special conditions are met, e.g., when mitigating surface subsidence triggered by abandoned workings (Siriwardane et al. 2003). In such situations, the backfill method is relatively special, usually using the method of pumped slurry injection into the gob (PSIB) from surface boreholes (Lokhande et al. 2005). For example, in the USA, PSIB was first successfully conducted for abandoned room-and-pillar structures beneath built-up areas in Wyoming in the 1970s and it has been 
shown to perform well in controlling the development of sinkholes (Colaizzi et al. 1981), followed by field tests in West Virginia in 1998 (Siriwardane et al. 2003). In addition to this objective, research has covered backfilling under room and pillar mining for the purpose of obtaining a high recovery rate (Donovan and Karfakis 2004), especially when mining under surface structures or rivers (Gandhe et al. 2005; Wang et al. 2011).

Panel and pillar mining, also denoted as longwall partial extraction (despite longwall, the panel width is generally a few tens of meters), was first introduced by British mining engineers in 1950s (Salamon 1991). It has been widely and successfully adopted in the UK (Wardell and Webster 1957; Salamon 1991), Australia (Kapp 1984) and China (Xu 2011), etc. Under panel and pillar mining, the final surface subsidence factor (the ratio of maximum surface subsidence to the mining height) is generally less than 0.1 , with surface subsidence being well controlled and surface buildings being protected. Therefore, backfilling is also not requried. However, some successful field trials (unreported) in terms of backfilling under panel and pillar mining, have been conducted in China in recent years; such trials aimed at increasing the recovery rate during panel and pillar mining on condition that surface structures can be protected, e.g., in the Bucun coal mine and the Daizhuang coal mine in Shandong Province.

Both room and pillar mining and panel and pillar mining take the principle of partial extraction, i.e., some remaining pillars support the ground and thus control surface subsidence. Such mining layout inevitably results in a low recovery rate of coal resources, whereas longwall mining overcomes this shortcoming at the high expense of causing the most serious surface subsidence issues. In China, nonpillar longwall panel layout is typically appllied for the purpose of achieving a high recovery rate or gate supporting, which means no pillar or a narrow pillar (around $5-10 \mathrm{~m}$ ) is left between the adjacent longwall panels. Mining with such panel layouts induces very serious subsidence-related issues; thus, some special mining method should be used during longwall extraction under surface structures, e.g., mining with backfill. For longwall mining, there are relatively more filling methods, e.g., gob backfill, grout injection into the caved zone and grout injection in bed separation zone (Palarski 2004; Xu et al. 2006). The first one is the most traditional and common method, which is referred to as complete backfill. More than a decade, complete backfill has been well developed in China (Qian et al. 2003; $\mathrm{Xu}$ et al. 2004). It appears that complete backfill techniques have provided a new path for the Chinese coal mines that suffer from mining under populated-areas for long, in particular for those in the old mining districts.

This paper attempts to discuss the surface subsidence control. First, we make a brief overview on the gob backfill technique and collected subsidence factors for longwall panels using complete backfill technique. On this basis, we discuss the surface subsidence control effect. Finally, a concept of separated longwall panel layout using complete backfill is proposed, together with a conceptual design method. This study can facilitate understanding surface subsidence control effect of complete backfill techniques.

\section{Subsidence control effect of complete backfill}

\subsection{Review on complete backfill}

\subsubsection{Difficulties in backfilling for longwall mining}

Gob backfill involves placing specific material into the mined-out area for the purpose of supporting overburden. For longwall mining, gob backfill is also called complete backfill. Typically, there are three primary difficulties for coal mines to implement backfill (Li et al. 2008), of which one is that the low productivity with backfill cannot coordinate with the high mining production. In general, the coal productivity of 1 million tons per year cannot be gained for a complete backfilling longwall face, which is far from the requirements of a high-efficient modern coal mine. In addition, the lack of the backfill material is also a consideration for mining with backfill, in particular for the un-cemented backfill typically using coal waste and/or fly ash as the backfilling material, as such materials commonly hold just $10 \%-20 \%$ and $20 \%-30 \%$ of raw coal produced (by mass), respectively. For example, the Indian mining industry is facing an acute shortage of river sand because of its increasing application in civil engineering (Mishra and Das 2010). Worse still, the capital cost of backfilling is too high for most coal mines, usually up to RMB 100 Yuan/t of coal in China. Such difficulties may explain that backfilling is always the final choice for the coal mines to extract under surface structures, although this technique has been conducted in several countries.

\subsubsection{Complete backfill technique}

According to Grice (1998), one of the earliest records of backfilling as a discrete technique in Australia was the placement of aggregate from lead jig wastes at Mount Isa in 1933, both for disposal purposes and for stabilizing the working areas by providing an improved platform instead of subsidence control, while coal mining in Australia has not traditionally used backfill. By contrast, such technique has been widely used in the Polish coal mining industry for the purpose of subsidence control and for enabling thick 
seam extraction methods, with the most common method of hydraulic backfill with sand (HBS) (Palarski 1989, 2004). The same function has served in the Indian coal mines (Lokhande et al. 2005).

Early in 1912, the Fushun Mining Bureau conducted small-scale tests of HBS for the first time in China (Chen 1992). However, the objective of this trial was not to control surface subsidence. Later in the 1960s, HBS was implemented to mine the coal pillar (seam thickness of $20 \mathrm{~m}$ ) for a machine repair shop by the Shengli coal mine in the Fushun Mining Bureau. This represented the first successful attempt to control subsidence using such complete backfill technique, followed by several HBS trials in other coal mines (Xu et al. 2006). In general, the objective of most of these HBS trials was not to mitigate subsidence but to provide supports for the higher slice of the thick seam during mining of the lower slice. The HBS technique has such disadvantages as low efficiency and complex backfill system, which prevent it from a popularization in the Chinese coal mining industry. Finally, this technique died out in 1990s.

More than a decade, backfill technique has been paid great considerations and been developed well in China, as the benefits including subsidence control and mitigation of surface structure damage can be gained (Qian et al. 2003; $\mathrm{Xu}$ et al. 2004). Typically, researchers have developed three main complete backfill techniques: paste backfill (Zhou et al. 2004), solid backfill (Miao et al. 2010) and high water material backfill (HWMB) (Feng et al. 2010). Overall, the significantly distinguishing characteristics among these techniques are the backfill material and the corresponding backfilling process, backfilling system, level of mechanization and the efficiency. However, such techniques essentially involve filling the mined-out space before the roof caves as soon as the face supports advance.

Paste backfill involves delivering the toothpaste-like slurry (i.e., paste) into mined-out area by pump; the paste, which does not dehydrate, is generally made from coal waste, fly ash, river sand, weathered sand, industrial slag, poor soil and urban solid waste, etc. (Zhou et al. 2004). China coal mines began the field test on paste backfill mining in 2004. Since then, the Fengfeng, Jiaozuo, Zibo, Xinwen, Zaozhuang, Feicheng and other mining bureaus have applied this technique. Backfill unit cost is usually up to $>$ RMB 100 Yuan/t of coal.

Solid backfill involves throwing or delivering solid materials (most common: waste rock) to the mined-out area by machinery (Miao et al. 2010). Up to date, Xinwen, Huaibei, Wanbei, Pingdingshan, Yanzhou, Jining, Kailuan, Xishan, Lu'an and Wuhai bureaus have carried out waste rock backfill mining applications. The unit cost is usually not $<100 \mathrm{RMB} / \mathrm{t}$ of coal.
High water material backfill uses high water material (HWM) as the backfill material (Feng et al. 2010). HWM is featured for its high volumetric content of water, up to $85 \%-97 \%$; it is a binding material, made of two materials: A and B (Feng et al. 2010). Good liquidity, little water segregation in the working face and few occurrences of pipeline block make HWMB more attractive. However, the biggest shortcoming is that HWM has weak resistance to the weathering and high temperature, and its long-term stability is relatively low. Backfill system of HWMB is significantly simplified compared with other backfill mining methods, and the unit cost is up to RMB 90-120 Yuan/t of coal. China coal mines commenced HWMB mining test in Taoyi Mine of Jizhong Energy Handan Mining Group in 2008. Up to date, Handan, Linyi, Yongcheng, Xingtai, Zibo, Fuxin, Huaibei, Jincheng and other mining bureaus have carried out HWMB mining applications. Detailed information on backfill mining methods in China are indicated in the publications of $\mathrm{Xu}$ et al. (2011) and Xuan et al. (2013).

\subsection{Inadequate subsidence control effect}

\subsubsection{Permissible safe surface deformations for structures}

As mentioned above, for the Chinese coal mines, the primary purpose of backfilling is to control surface subsidence and thus to mine under some specific surface structures, for the most cases, village buildings. Therefore, the engineering goals are preventing such surface constructions from mining damage. In general, those indicators are used to evaluate the mining effect on the ground surface and constructions: vertical displacement, horizontal displacement, inclination, strain and curvature, among which the last three are the primary damage cause to the constructions, in particular the strain. However, whether the constructions suffering damage depends also on its tolerant deformations, which differ much for individuals. Therefore, a standard deformation is needed when implementing mining with backfill under buildings to confirm that the constructions remain safe during and following extraction.

The State Bureau of Coal Industry (2000) classified the damage levels for the brick-concrete structures (Table 1). Generally, level I indicates that no macroscopic fissures occur to the structures and the coal company need not to pay out. For example, Luo et al. (2004) used the standard of tensile strain of $2.0 \mathrm{~mm} / \mathrm{m}$ to guide a successful extraction of the Pittsburgh coal seam under a mine refusedisposal facility. The National Coal Board (1975) recommended a classification of damages with five levels for the buildings in terms of the length of structure and mininginduced strain (Fig. 1). For example, 10-m-length structure 
Table 1 Classification of subsidence damage to the brick-concrete structures (State Bureau of Coal Industry 2000)

\begin{tabular}{llllll}
\hline Damage level & \multicolumn{2}{l}{ Surface deformations } & & Classification & Structural processing \\
\cline { 2 - 5 } & $\begin{array}{l}\text { Strains } \varepsilon \\
(\mathrm{mm} / \mathrm{m})\end{array}$ & $\begin{array}{l}\text { Curvatures } K \\
\left(\mathrm{~mm} / \mathrm{m}^{2}\right)\end{array}$ & $\begin{array}{l}\text { Inclinations } i \\
(\mathrm{~mm} / \mathrm{m})\end{array}$ & & \\
\hline I & $\leq 2.0$ & $\leq 0.2$ & $\leq 3.0$ & Negligible damage & No repair \\
II & $\leq 4.0$ & $\leq 0.4$ & $\leq 6.0$ & Very slight damage & Light repair \\
III & $\leq 6.0$ & $\leq 0.6$ & $\leq 10.0$ & Slight damage & Minor repair \\
IV & $>6.0$ & $>0.6$ & $>10.0$ & Medium damage & Medium repair \\
& & & & Severe damage & Heavy repair \\
\hline
\end{tabular}

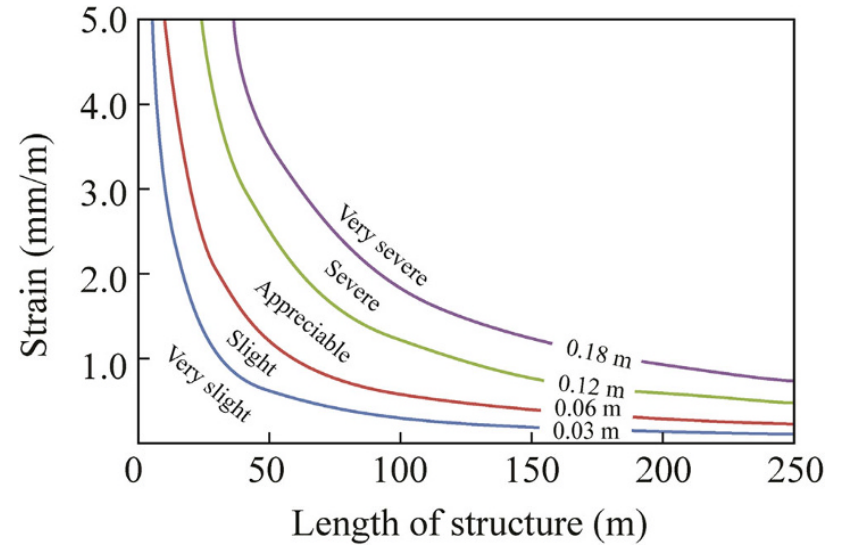

Fig. 1 Relationship of damage to length of structure and horizontal ground strain (modified from National Coal Board 1975)

would suffer very slight damage triggered by mining activity when the horizontal strain is less than $3 \mathrm{~mm} / \mathrm{m}$, which means hair cracks in plaster, perhaps isolated slight fracture in the building, not visible on outside.

\subsubsection{Mining-induced surface subsidence using complete backfill}

Although gob backfill is also called complete backfill, none of backfill techniques can obtain a filling ratio of $100 \%$. This is attributed not only to backfilling process and mechanical properties of backfill material (Karfakis et al. 1996), but also to the mining-induced motion law of roof strata. The filling ratio of $<100 \%$ has been confirmed by practices of mining with backfill in different countries (Gandhe et al. 2005). Therefore, surface subsidence cannot be entirely avoided under backfilling. Typically, in the evaluation of surface subsidence under backfill, the term of effective extraction height is proposed (Singh and Singh 1985; Miao et al. 2010), which represents the actual thickness of voids transferred finally to the ground surface and is just part of the actual mining height. The ratio of
Table 2 Subsidence factors with hydraulic sand backfill (modified from Lokhande et al. 2005)

\begin{tabular}{ll}
\hline Country & Subsidence factor \\
\hline Ruhr coalfield, Germany & 0.20 \\
Upper Silesia, Poland & 0.12 \\
North \& Pas-de-calais coalfield, France & $0.25-0.35$ \\
British coalfield & $0.15-0.20$ \\
Kuho (II) colliery, Japan & 0.19 \\
Kamptee coalfield, India & $0.05^{*}$ \\
Fushun and Xinwen coalfileds, China & $0.06-0.30$ \\
\hline
\end{tabular}

* Lokhande et al. (2005) attributed good subsidence control effect to strong overlying rock in Indian coal mines

effective extraction height to actual mining height is called subsidence factor under backfill.

Lokhande et al. (2005) collected subsidence factors for backfilling workings in several countries and concluded that subsidence factors were $0.05-0.30$ using HBS, which are consistent with that $(0.06-0.30)$ in China (Table 2). Zhou (2010) measured subsidence factors for longwall panels using paste backfill in China and found them to be 0.09-0.26 (Table 3), close to that using HBS. In general, the greater compaction and the lower compression of backfill material, the less subsidence factor is. Paste possesses high density and high strength, therefore surface subsidence and ground control effect is good. By contrast, the compactness of waste rock is relatively low, and surface subsidence control effect is not as good as paste backfill. Karfakis et al. (1996) concluded that if improving ground control is the only reason for backfilling, coal refuse alone does not appear to be a suitable stowing material. The control effect of HWMB is between the other two. Although no reports on subsidence factor for waste rock backfill and HWMB were issued, it can be inferred that subsidence factor may vary $0.10-0.30$.

Using numerical modeling, Xuan et al. (2012) concluded that when the mining height is certain, small mining width $[3 \mathrm{~m}$ for the geological and mining conditions 
Table 3 Subsidence factor for a critical extraction width using paste backfill (Zhou 2010)

\begin{tabular}{|c|c|c|c|}
\hline Test site & $\begin{array}{l}\text { Mining } \\
\text { height }(\mathrm{m})\end{array}$ & $\begin{array}{l}\text { Subsidence } \\
\text { factor }\end{array}$ & Remark \\
\hline Taiping coal mine, China & 9.00 & $0.15-0.26$ & Longwall mining without pillars (mean panel width: $180 \mathrm{~m}$ ) \\
\hline Zhucun coal mine, China & 1.34 & $0.09-0.15$ & Longwall mining without pillars (mean panel width: $120 \mathrm{~m}$ ) \\
\hline Xiaotun coal mine, China & 5.50 & $0.15-0.20^{*}$ & Longwall mining without pillars (mean panel width: $105 \mathrm{~m}$ ) \\
\hline Daizhuang coal mine, China & 2.66 & $<0.10^{*}$ & $\begin{array}{l}\text { Extraction of pillars left in the area where panel and pillar } \\
\text { mining method was adopted }\end{array}$ \\
\hline
\end{tabular}

* Inferred from subcritical mining condition

(Xuan et al. 2012)] could guarantee buildings without damage; once mining width is increased, subsidence control effect of complete backfill becomes worse, leading surface structures to more than damage level I classified by the State Bureau of Coal Industry (2000) (Fig. 2).

For further explanation, the probability integral method (Liu and Liao 1965) recommended by the State Bureau of Coal Industry (2000) is applied to calculate horizontal deformations of an assumed mining area with the cover depth of $400 \mathrm{~m}$. Assuming such geological and mining conditions: flat seam, medium hard overlying strata and an infinite panel length in the strike. Two sets of mining height are examined: 3 and $5 \mathrm{~m}$. Here, taking damage level I by the State Bureau of Coal Industry (2000) as a critical failure criterion for surface structures. According to Liu and Liao (1965) the horizontal strain along the major cross section above the mining area can be expressed as:

$$
\begin{aligned}
\varepsilon(x)= & -\frac{2 \pi b M q}{r^{2}} x \exp \left(-\pi \frac{x^{2}}{r^{2}}\right)+\frac{2 \pi b M q}{r^{2}}(x \\
& -W) \exp \left[-\pi \frac{(x-W)^{2}}{r^{2}}\right],
\end{aligned}
$$

where $\varepsilon(x)$ is horizontal strain for an arbitrary $x$ from the left edge of the panel, $b$ is the horizontal movement factor, $M$ is mining height, $q$ is subsidence factor using complete backfill, $r$ is the radius of main influence. Here, $r=H / \tan \beta$, where $H$ is cover depth, $\tan \beta$ is the tangent of the angle of major influence and $W$ is panel width.

Based on a traditional crtical panel without backfilling, the values of $b$ and $\tan \beta$ are taken as 0.32 and 1.8, respectively. Setting the panel width as $620 \mathrm{~m}$ (a supercritical width) and surface subsidence factor using complete backfill as three sets: 0.1, 0.2 and 0.3. The horizontal strain profiles are obtained using Eq. (1) (Fig. 3). At the mining height of $3 \mathrm{~m}$, even if the backfill effect is poor $(q=0.3)$, the damage of ground buildings still can be protected within level I under the supercritical panel width,
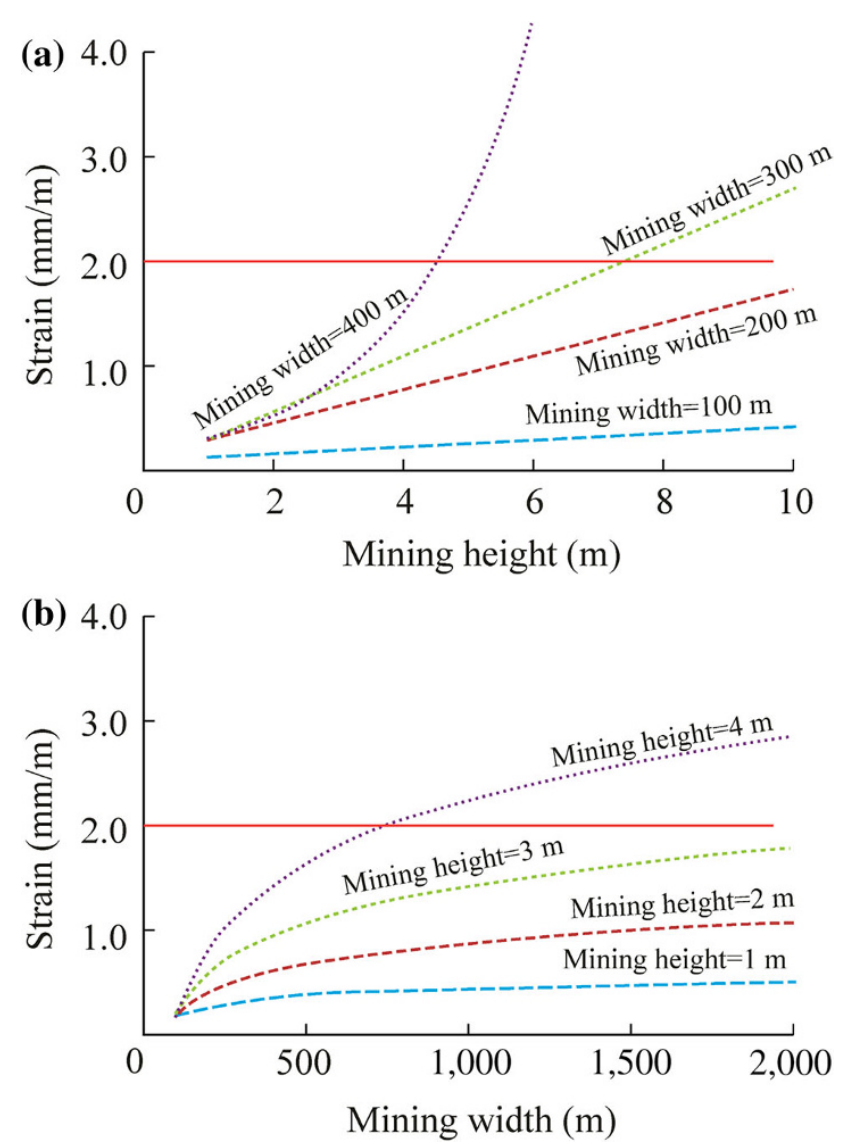

Fig. 2 Relationship of strains to mining height (a) and panel extraction (b). (Modified from Xuan et al. (2012))

whereas at the mining height of $5 \mathrm{~m}$, as the filling effect get worse (i.e., subsidence factor of 0.2), the damage level of surface structures begins to be $>$ I (Fig. 3). Thus, on the aspect of surface structure protection, if the mining height becomes large, mining with both non-pillar panel layout and complete backfill is no longer applicable. However, the backfill technique is not impossible to be used only if the panel layout is reasonably adjusted, i.e., in such 

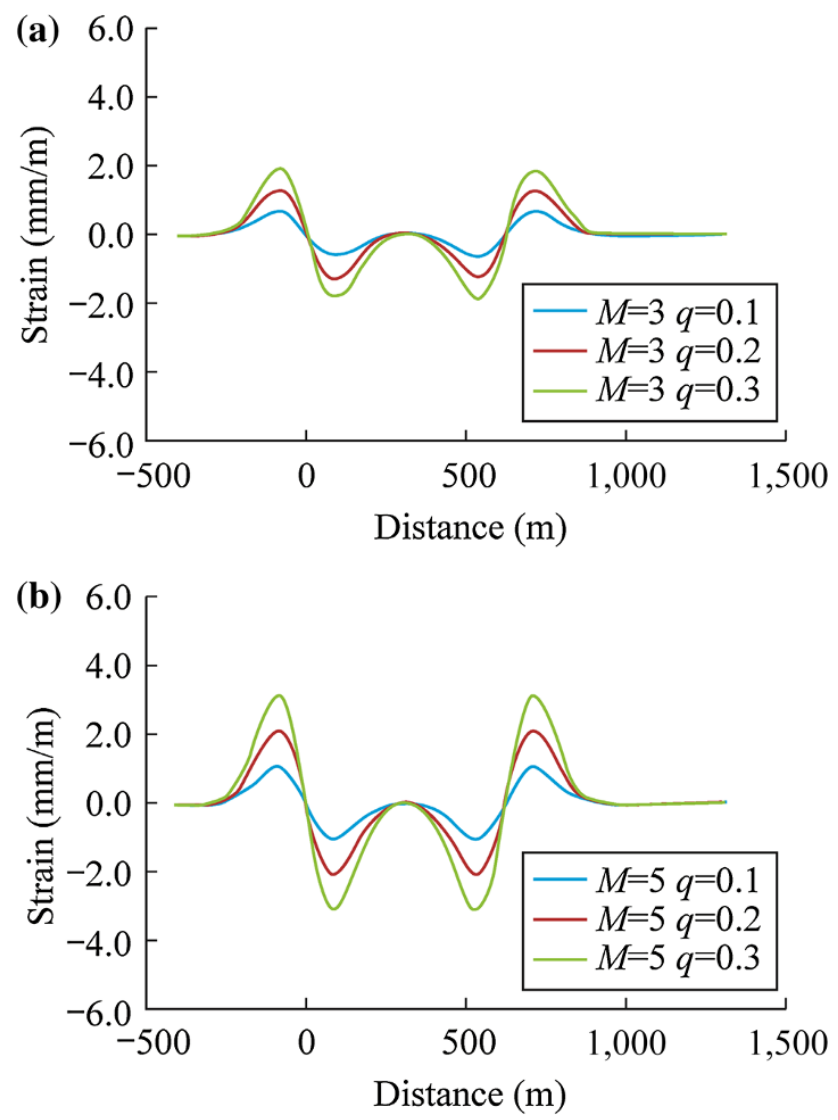

Fig. 3 Strain profiles in major cross-section for varied mining heights $(M)$ and surface subsidence factor $(q)$

situations, an innovative backfilling panel layout should be used, namely separated backfill mining (refer to Sect. 3).

\section{Design principle and method of separated backfill mining}

\subsection{Principle}

Separated backfill mining refers to implementing backfill mining by limiting the longwall panel to a subcritical width; a chain pillar should be left to insure that the adjacent panels are in the subcritical conditions (Fig. 4). Separated backfill mining takes two principles as follows. One is that surface movement and deformation are slight at a narrow panel width (subcritical condition), and the other is that with the existence of stable coal pillars, full subsidence can be avoided following extraction of adjacent panels.

For a long time, researchers have found that when the panel has a narrow width, the surface movement and deformation are small (National Coal Board 1975; State Bureau of Coal Industry 2000). The State Bureau of Coal

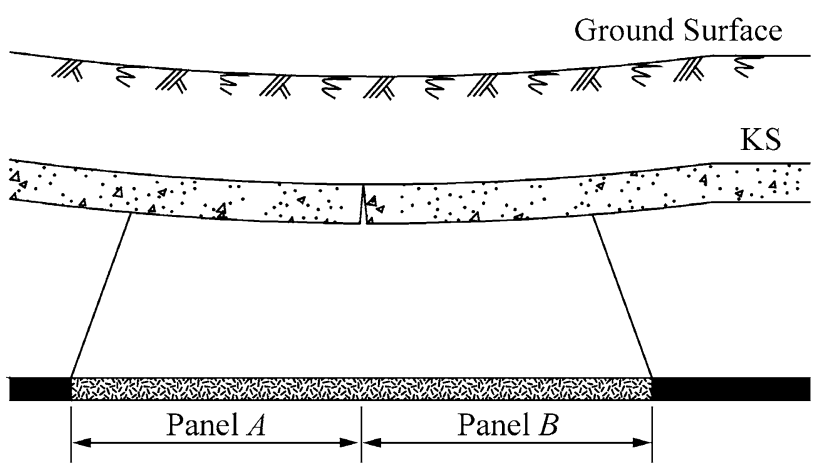

(a) Non-pillar panel layout using complete backfill
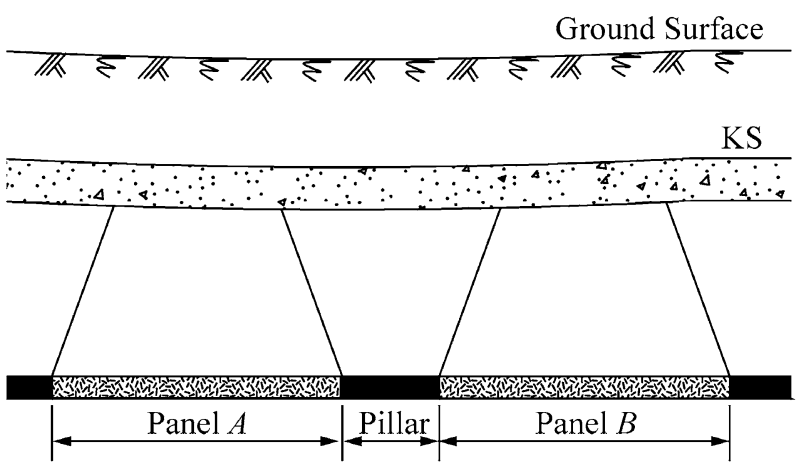

(b) Separated panel layout using complete backfill

Fig. 4 Schematic of non-pillar panel layout using complete backfill (a) and separated panel layout using complete backfill (b)

Industry (2000) has pointed out that in surface subsidence prediction for a narrow panel width (less than the cover depth), the prediction parameters need to be reduced, e.g., $\tan \beta$ shown in Fig. 5. Xu et al. (2005) reveals the mechanism of such phenomenon through further studies, i.e., some strong and thick strata in the overburden (called the key strata) have a control effect on surface subsidence; if the key strata do not break, surface subsidence is quite small. Obviously, in a condition of a narrow panel width, the key strata have a relatively narrow span and do not break. Therefore surface movement and deformation are relatively small.

By incorporating Fig. 5 into surface subsidence prediction, horizontal strain profiles are generated for varied panel widths at the mining height of $5 \mathrm{~m}$ using complete backfill with subsidence factor of 0.3 (Fig. 6). A good control effect can be gained at a narrow panel width (i.e., $<150 \mathrm{~m}$ ); if the panel width is $>150 \mathrm{~m}$, surface damage level would be $>$ I (Fig. 6). This result suggests that, under a specific geological condition, surface subsidence can be effectively controlled by appropriately selecting a subcritical panel width, even at a large mining height.

Another factor affecting surface subsidence is the width of chain pillar between the adjacent panels. A critical mining condition can be avoided on condition that the 


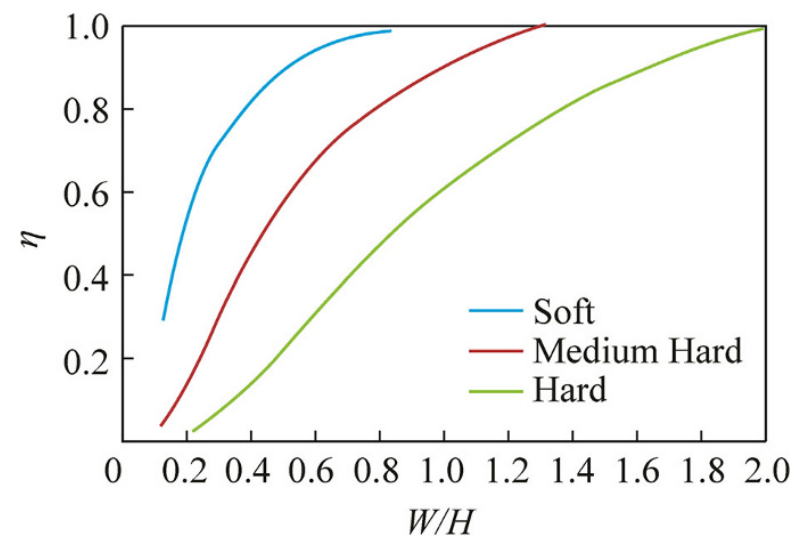

Fig. 5 Reduction factor $(\eta)$ of the tangent of major influence angel. Notes $W$ is the the panel width; $H$ is the overburden depth (modified from the State Bureau of Coal Industry 2000)

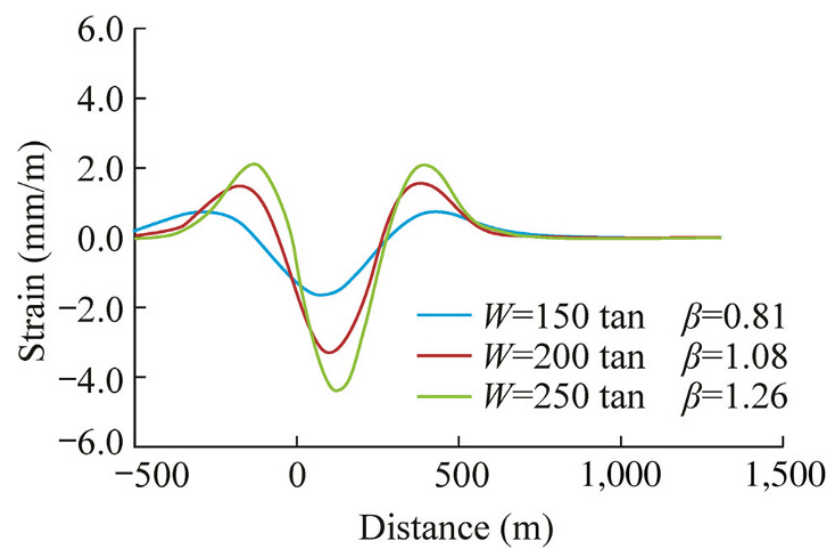

Fig. 6 Strain profiles in major cross-section for varied mining widths $(W)$ under mining height of $5.0 \mathrm{~m}$ and surface subsidence factor of 0.3

stable chain pillars are left between adjacent subcritical panels. Therefore, surface deformations will be smaller than that caused by the panels without chain pillars, and surface structures can be prevented from damage.

\subsection{General design method}

\subsubsection{Panel width}

According to the control action of key strata on surface subsidence ( $\mathrm{Xu}$ et al. 2005), panel width can be designed by stabilizing the most upper key stratum (primary key stratum, KS3) during the extraction (Fig. 7). If the primary key stratum is not relatively strong and hard, the
Ground surface

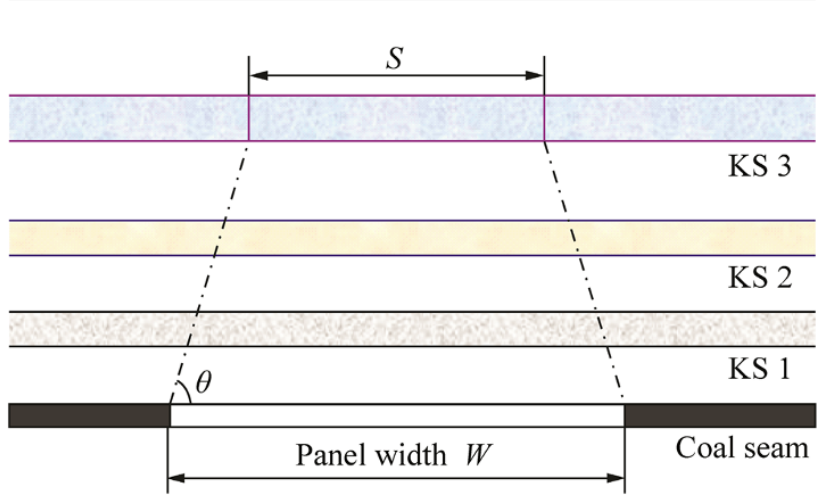

Fig. 7 Schematic of panel width design using concept of key strata. Notes $S$ is limited span of key strata and $\theta$ is the break angle of overburden strata

panel width can be designed based on a lower key stratum (e.g., KS2 in Fig. 7). The limit span of the key strata can be calculated based on the beam model. The panel width $(W)$ can be expressed as:

$W \leq S+2 D \tan \theta$,

where $D$ is the distance from the panel to the key stratum, $\theta$ is the break angle of the rock strata.

\subsubsection{Pillar width}

In order to obtain a subcritical mining condition, chain pillars should be remain stable. Typically, the conventional approach of the stability of coal pillar is based on the factor of safety (FOS) expressed as follows:

$\mathrm{FOS}=S / P$

where, $S$ is the strength of the coal pillar, $P$ is vertical stress applied on the coal pillar.

$P$ can be calculated based on tributary loading. In the calculation of $S$, several formulae have been put forward. Du et al. (2008) have made a comprehensive review. In general, there are two types of coal pillar strength calculation method: empirical method (Bieniawski 1981) and analytical method (Wilson and Ashwin 1972; Wilson 1983). Among the empirical methods, the commonly used is the Bieniawski formula (Bieniawski 1981)

$S=S_{\mathrm{c}}(0.64+0.36 \mathrm{~W} / \mathrm{M})$

where, $S_{\mathrm{c}}$ is the strength of cubic specimen of coal, $W$ is pillar width, $M$ is pillar height.

Furthermore, Bieniawski (1992) pointed out that, a FOS of 1.3 can guarantee the stability of coal pillars for longwall mining. Therefore, for longwall mining with backfill, 
a value of $>1.3$ is an acceptable FOS for the chain pillars. It should be noted that the Bieniawski formula is suitable for the square coal pillars. By considering the influence of length of coal pillars, Mark and Chase (1997) redefined the Bieniawski formula as the Mark-Bieniawski formula:

$S=S_{\mathrm{c}}\left(0.64+0.54 \frac{W}{M}-0.18 \frac{W^{2}}{L M}\right)$

where, $L$ is the length of coal pillars. For longwall mining with backfill, the Mark-Bieniawski formula seems more reasonable.

\section{Discussion and conclusions}

From the worldwide backfill practices, it can be concluded that subsidence factor using complete backfill is usually 0.1-0.3 depending on the backfill materials (e.g., river sand and paste). In the practice of Chinese longwall, non-pillar longwall panel layout is typically used, which means no pillar or a narrow pillar (around 5-10 m) is left between the adjacent longwall panels. Using complete backfill under such a panel layout, surface structures can be protected against damage at a relatively small mining height, whereas surface subsidence will be uncontrolled at a relatively large mining height in a critical mining condition. In such cases, the separated backfill mining method should be used. The determination of this critical mining height is a site-specific problem and it depends on geological and mining conditions. Probably, it can be speculatively inferred that a final surface subsidence of $0.6 \mathrm{~m}$ could be regarded as a threshold for determining the critical mining height, e.g., separated backfill mining should be used at the mining height of $3.0 \mathrm{~m}$ with surface factor of $>0.2$, the mining height $4.0 \mathrm{~m}$ with the surface factor of $>0.15$.

In addition to the backfilling, separated backfill mining takes the principles of subcritical extraction and partial extraction as follows. First, surface movements and deformations are slight at a narrow panel width (i.e., a subcritical condition), and the other is that with the existence of stable coal pillars, full subsidence can be avoided following extraction of adjacent panels. Therefore, even at a large mining height, surface structures can be protected. In practice, panel width can be designed based on the key strata in the overburden, and the width of chain pillar can be determined based on the criterion of stability with a FOS of 1.3. It should be noted that this is just a general design approach and further study is required regarding this issue, e.g., effect of pillar width on surface subsidence.

Inevitably, the recovery rate of coal reserves is decreased by using separated backfill mining method comparing with that using non-pillar mining method. Considering only the economic benefit, if the sum of backfilling cost and the benefits of loss of coal pillars is greater than the relocation costs of surface structures, it seems to be more cost-effective for coal enterprises to apply the removal of structures. However, the social environment and social benefits should also be taken into consideration, i.e., whether ground subsidence is permitted or not and whether the residents are willing to relocate. These are indeed difficulties that the Chinese coal enterprises have always been challenged. Therefore, on the respect of surface subsidence control and surface structures protection, the implementation of separated backfill mining is the best way for gob backfill.

Open Access This article is distributed under the terms of the Creative Commons Attribution License which permits any use, distribution, and reproduction in any medium, provided the original author(s) and the source are credited.

\section{References}

Bieniawski ZT (1981) Improved design of coal pillars for us mining conditions. In: Peng SS (ed) Proceedings of the 1st conference on ground control in mining, Morgantown, pp 13-22

Bieniawski ZT (1992) A method revisited: coal pillar strength formula based on field investigations. In: Proceedings of the Second International Workshop on Coal Pillar Mechanics and Design. US. Bureau of Mines, IC9315, pp 158-165

Chen D (1992) Annuals of Shengli Coal Mine in Fushun Mining District 1901-1985. Liaoning People's Publishing House, Shenyang

Colaizzi GJ, Whaite RH, Donner DL (1981) Pumped-slurry backfilling of abandoned coal mine workings for subsidence control at Rock Springs, WY. US Bureau of Mines, IC 8846

Donovan JG, Karfakis MG (2004) Design of backfilled thin-seam coal pillars using earth pressure theory. Geotech Geol Eng 22(4):627-642

Du X, Lu J, Morsy K, Peng S (2008) Coal pillar design formulae review and analysis. In: Peng SS, Mark C, Finfinger GL, Tadolini SC, Khair AW, Heasley KA, Luo Y (eds) Proceedings of the 27th International Conference on Ground Control in Mining, Morgantown, pp. 254-261

Feng GM, Sun CD, Wang C, Zhou Z (2010) Research on goaf filling methods with super high-water material. J China Coal Soc 35(12):1963-1968 (in Chinese)

Gandhe A, Venkateswarlu V, Gupta RN (2005) Extraction of coal under a surface water body-a strata control investigation. Rock Mech Rock Eng 38(5):399-410

Grice T (1998) Underground mining with backfill. In: Proceedings of the 2nd Annual Summit-Mine Tailings Disposal Systems, Brisbane, pp. 234-239

Ilgner HJ (2000) The benefits of ashfilling in South African coal mines. Coal-the Future, 12th International Conference on Coal Research. South African Institute of Mining and Metallurgy, Johannesburg, pp 279-288

Kapp WA (1984) Mine subsidence and strata control in the Newcastle district of the northern coalfield New South Wales, Doctor of Philosophy thesis, Department of Civil and Mining Engineering, University of Wollongong, 1984

Karfakis MG, Bowman CH, Topuz E (1996) Characterization of coalmine refuse as backfilling material. Geotech Geol Eng 14(2):129-150 
Li XS, Xu JL, Zhu WB, Lai WQ (2008) Choice of coal mine partialfilling technology according to balance between mining and filling. Journal of Liaoning Technical University (Natural Science) 27(2):168-171 (in Chinese)

Liu BC, Liao GH (1965). Surface movements in coal mines. China Industry Publishing House, Beijing

Lokhande RD, Prakash A, Singh KB, Singh K (2005) Subsidence control measures in coalmines: a review. J Sci Ind Res 64(5):323-332

Luo Y, Ping SS, Mishra M (2004) Longwall mining under a mine refuse-disposal facility. Min Eng 56(9):89-93

Mark C, Chase FE (1997) Analysis of retreat mining pillar stability (ARMPS). In: Proceedings: New Technology for Ground Control in Retreat Mining, NIOSH, IC 9446, Pittsburgh, pp 17-34

Miao XX, Zhang JX, Guo GL (2010) Study on waste-filling method and technology in fully-mechanized coal mining. J China Coal Soc 35(1):1-6 (in Chinese)

Mishra DP, Das SK (2010) A study of physico-chemical and mineralogical properties of Talcher coal fly ash for stowing in underground coal mines. Mater Charact 61(11):1252-1259

National Coal Board (1975) Subsidence engineers' handbook. Mining Department, National Coal Board, London

Palarski J (1989) The experimental and practical results of applying backfill. In: Hassani FP, Scoble MJ, Yu TR (eds) Innovations in Mining Backfill Technology. Balkema, Rotterdam, pp 33-37

Palarski J (2004) Selection of a fill system for longwall in coal mines. In: Proceedings of the 8th International Symposium on Mining with Backfill, Beijing, pp 74-80

Peng SS (1992) Surface subsidence engineering. Society for Mining, Metallurgy, and Exploration, Inc., Littleton

Qian MG, Xu JL, Miao XX (2003) Green technique in coal mining. J China Univ Min Technol 32(04):5-10 (in Chinese)

Salamon MDG (1991) Partial Extraction to Control Surface Subsidence Due to Coal Mining. In: Proceedings of the 32nd U.S. Symposium on Rock Mechanics (USRMS), Norman, Oklahoma pp 861-870

Singh TN, Singh B (1985) Model simulation study of coal mining under river beds in India. Int J Mine Water 4(3):1-9

Siriwardane HJ, Kannan RS, Ziemkiewicz PF (2003) Use of waste materials for control of acid mine drainage and subsidence. J Environ Eng 129(10):910-915
State Bureau of Coal Industry (2000) Regulations of coal pillar design and extraction for buildings, water bodies, railways, main shafts and roadways. Coal Industry Press, Beijing

Wang H, Poulsen BA, Shen B, Xue S, Jiang Y (2011) The influence of roadway backfill on the coal pillar strength by numerical investigation. Int J Rock Mech Min Sci 48(3):443-450

Wardell K, Webster NE (1957) Some surface observations and their relationship to movement underground. Proceedings of the European Congress on Ground Movement. The University of Leeds, Leeds, pp 141-148

Wilson AH (1983) The stability of underground workings in the soft rocks of the Coal Measures. Int J Min Eng 1:91-187

Wilson AH, Ashwin DP (1972) Research into the determination of pillar size. The Mining Engineer 141:409-430

$\mathrm{Xu}$ JL (2011) Green mining of coal mines. China University of Mining \& Technology Press, Xuzhou

Xu JL, Zhu WB, Lai WQ, Qian MG (2004) Green mining techniques in the coal mines of China. $J$ Mines Metals Fuels 52(12):395-398

Xu JL, Qian MG, Zhu WB (2005) Study on influences of primary key stratum on surface dynamic subsidence. Chinese J Rock Mech Eng 24(5):787-791 (in Chinese)

Xu JL, Zhu WB, Li XS, Lai WQ (2006) Study of the technology of partial-filling to control coal mining subsidence. J Min Safety Eng 23(1):6-11 (in Chinese)

Xu JL, Xuan DY, Zhu WB (2011) Present aspects and prospect of coal mining methods using backfill. Min Technol 11(03):24-30 (in Chinese)

Xuan D, Xu J (2014) Grout injection into bed separation to control surface subsidence during longwall mining under villages: case study of Liudian coal mine, China. Nat Hazards 73(2):883-906. doi:10.1007/s11069-014-1113-8

Xuan DY, Xu JL, Zhu WB (2012) Research on applicability of coal mining with backfilling. China Coal 38(05):44-48 (in Chinese)

Xuan D, Xu J, Zhu W (2013) Backfill mining practice in China coal mines. J Mines Metals Fuels 61(7-8):225-234

Zhou HQ (2010) Development direction and study of paste backfill in china's coal mines. Presentation in the 3rd International Symposium on Green Mining, Xuzhou

Zhou HQ, Hou CJ, Sun XK, Qu QD, Chen JD (2004) Solid waste paste filling for none-village-relocation coal mining. J China Univ Min Technol 33(2):154-158 (in Chinese) 